Canadian Journal of Higher Education

Revue canadienne d'enseignement supérieur

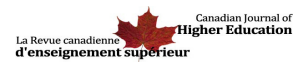

\title{
Using a Project Blog to Promote Student Learning and Reflection
}

\author{
Paisley Worthington, Jennifer Reniers, Dale Lackeyram et John Dawson
}

Volume 48, numéro 3, 2018

URI : https://id.erudit.org/iderudit/1057132ar

DOI : https://doi.org/10.7202/1057132ar

Aller au sommaire du numéro

\section{Éditeur(s)}

Canadian Society for the Study of Higher Education

ISSN

2293-6602 (numérique)

Découvrir la revue

Citer cet article

Worthington, P., Reniers, J., Lackeyram, D. \& Dawson, J. (2018). Using a Project Blog to Promote Student Learning and Reflection. Canadian Journal of Higher Education / Revue canadienne d'enseignement supérieur, 48(3), 125-140.

https://doi.org/10.7202/1057132ar
Résumé de l'article

Selon la recherche, les étudiants en enseignement supérieur utilisant un blogue pour satisfaire aux exigences des cours montrent un niveau élevé de réflexion, de sentiment d'appartenance et de connaissances liées au cours. Le blogage fournit aux étudiants un médium prometteur pour s'engager dans la réflexion durant un stage coopératif. Le blogue peut guider un groupe en encourageant une communication claire, une documentation des ressources et un libre partage des idées. Dans ce document, nous décrivons une analyse qualitative des articles de blogue de trois étudiants en stage. Les étudiants ont largement utilisé le blogue : pour communiquer, pour faire des " remue-méninges, " pour évaluer la littérature et pour documenter des créations communes. Nous discutons les caractéristiques du projet qui pourraient avoir eu un impact sur l'utilisation répandue du blogue, avant de proposer des conseils à ceux qui s'intéressent à la mise en œuvre du blogage dans de tels projets.
Copyright (c) Paisley Worthington, Jennifer Reniers, Dale Lackeyram, John Dawson, 2018
Ce document est protégé par la loi sur le droit d'auteur. L'utilisation des services d’Érudit (y compris la reproduction) est assujettie à sa politique d'utilisation que vous pouvez consulter en ligne.

https://apropos.erudit.org/fr/usagers/politique-dutilisation/ 
Canadian Journal of Higher Education Revue canadienne d'enseignement supérieur

Volume 48, No. 3, 2018, pages 125 - 140

\title{
Using a Project Blog to Promote Student Learning and Reflection
}

Paisley Worthington, Jennifer Reniers, Dale Lackeyram, and John Dawson University of Guelph

\begin{abstract}
Research on the use of blogs in higher education suggests that students who blog as part of a course requirement demonstrate increased reflection, heightened feelings of connection, and increased course-related knowledge. Blogging provides a promising medium for students to engage in reflection on their participation in a cooperative education work term. Blogging can help guide a project by providing an encouraging place for team members to communicate clearly, document their work and other resources, and brainstorm ideas. In this paper, we describe a qualitative analysis of blog posts written by three students during a co-op placement. The students used the blog extensively and with multiple purposes: to reflect, to communicate, to brainstorm ideas, to evaluate literature, and to document team creations. We discuss the characteristics of the project and blog that may have contributed to its extensive use and provide recommendations for individuals interested in implementing a blog in similar projects.
\end{abstract}

\section{Résumé}

Selon la recherche, les étudiants en enseignement supérieur utilisant un blogue pour satisfaire aux exigences des cours montrent un niveau élevé de réflexion, de sentiment d'appartenance et de connaissances liées au cours. Le blogage fournit aux étudiants un médium prometteur pour s'engager dans la réflexion durant un stage coopératif. Le blogue peut guider un groupe en encourageant 
une communication claire, une documentation des ressources et un libre partage des idées. Dans ce document, nous décrivons une analyse qualitative des articles de blogue de trois étudiants en stage. Les étudiants ont largement utilisé le blogue : pour communiquer, pour faire des " remue-méninges, » pour évaluer la littérature et pour documenter des créations communes. Nous discutons les caractéristiques du projet qui pourraient avoir eu un impact sur l'utilisation répandue du blogue, avant de proposer des conseils à ceux qui s’intéressent à la mise en œuvre du blogage dans de tels projets.

\section{Introduction}

Colleges and universities are facing increasing pressure to provide students with the skills required to gain meaningful employment after graduation. Cooperative education (co-op) work placements, in which students gain work experience in a professional field as a part of their post-secondary education, can help students gain the skills and experience necessary for the workforce. According to Co-operative Education and Work-Integrated Learning Canada (n.d., para. 1), students must be "engaged in productive work" which is monitored by the co-op education program during the work placement. In addition, coop work terms must support "student learning goals, personal evaluation and reflection" (para. 1). Encouraging co-op students to contribute to a blog during their co-op work term can help students accomplish goals of both working to complete a project and engaging in learning and reflection on the project.

\section{The Use of Blogs in Higher Education}

Blogs are a ubiquitous but customizable digital medium existing as personal or professional websites archiving multimedia posts in reverse chronological order (Makri \& Kynigos, 2007). Bloggers often take on the roles of journalist, editor, and researcher simultaneously, filtering and retaining the most important information for strategic use in a post (Mortensen and Walker, 2002). Blogs provide space for bloggers to communicate, externalize their reasoning, reflect, and organize their thoughts into structured, coherent posts (de Andrés Martínez, 2012; Xie, Ke, \& Sharma, 2008). The skills required to write a blog involve the use of higher order cognitive skills such as communication, collaboration, critical thinking, and self-reflection (de Andrés Martínez, 2012; Sawmiller, 2010; Xie et al., 2008).

Research shows that the use of blogging in higher education is associated with numerous benefits for the learner, including heightening connectedness among students (Miceli, Murray, \& Kennedy, 2010), increased understanding of course concepts, and improved knowledge integration outside of class (Halic, Lee, Paulus, \& Spence, 2010). Students use class blogs in several ways, including discussing theories and concepts from the literature and reflecting on their own experiences (Yang, 2009). Students often report benefits of blogging. For example, Strampel and Oliver (2008) found that students agreed that a course-related blog was useful for allowing them to describe and critically reflect upon an action, event, or concept, and for helping them realize that others have differing views.

The successful use of blogs in university and college courses suggests that blogging may be an effective means of promoting learning in other contexts. Some research has exam- 
ined the use of blogs outside of the classroom environment. For example, Chu, Chan, and Tiwari (2012) examined the use of blogs by information management and nursing interns in Hong Kong. They found that students in the two cohorts used the blogs for different functions. Specifically, the management information students tended to use the blog for cognitive tasks such as sharing information, producing knowledge, or problem solving. In contrast, the nursing students tended to use the blog most frequently to engage in metacognitive and reflexive processes. In another study of the use of blogs in work-integrated learning, Edgar, Francis-Coad, and Connaughton (2013) found that physiotherapy students who were required to post to a blog during a work placement described blogging as a useful component of their placement, and some students indicated that they continued to access their previously published blog posts after graduation.

Research on the use of blogs in higher education, both within and outside of the classroom, has found mixed results on student engagement with and perceived effectiveness of blogging. Some research suggests that students engage more frequently or more deeply with blogging when instructors set clear guidelines and assign grades for blogging. For example, Chu et al. (2012) compared the frequency of blogging between two groups of students completing an internship. They found that students whose blogging was graded used the blogs more frequently than students whose blogs were not graded. Other research also points to the importance of providing students with structure for engaging in blogging. For example, Divitini, Haugaløkken, and Morken (2005) studied the use of a blog to support teacher education and found that students rarely engaged with the blog during the observation period. Students cited their heavy workload and a perceived lack of usefulness as barriers to using the blog. Churchill (2009) found that students agreed that blogging contributed to their learning during a postgraduate degree, but that they were motivated to blog due to course requirements. The students indicated that they would likely not continue to blog unless they were required to do so.

However, not all evidence suggests that grades and strict guidelines are necessary for students to engage in blogging in higher education. For example, Chu et al. (2012) found that students who were graded for blogging reported that the blogs were too formal, and they were only motivated to blog to earn the grade. Other research shows that in some cases, when students are instructed to write a required number of blog posts throughout the semester, they often complete only the minimum required posts to earn the associated grade (for example, de Andrés Martínez, 2012; Chretien, Goldman, \& Faselis, 2008).

\section{Using Blogs to Promote Learning and Reflection}

Blog use in and outside of the classroom in higher education is often intended to promote reflection, increase feelings of connection between class members, and promote understanding of course content. Reading and writing blog posts, and commenting on others' blog posts, can promote reflection by allowing bloggers to pose questions, challenge beliefs, and respond to questions and challenges from multiple perspectives (Yang, 2009). Blogs can encourage individuals to critically reflect upon their learning by providing an online venue for learners to communicate with others, describe their beliefs, and question their own and others' assumptions (Yang, 2009). Analyses of student blog posts show that blogging can encourage student learning by giving students a means to engage in cognitive, meta-cognitive-reflective, and affective learning (Chu et al., 2012). 


\section{The Current Study}

The current paper retrospectively analyzes blog posts authored by undergraduate students throughout a curriculum mapping project completed as a co-op work placement. We investigate how students used a private blog to guide the co-op project and to engage in learning and reflection. We examined the following three research questions:

Research Question 1: How frequently did students write blog posts?

Research Question 2: What content did students write about?

Research Question 3: What functions did the students' blog posts serve?

We conclude the paper with recommendations for implementing blogging to promote learning and reflection in similar higher education settings.

\section{Description of the Faculty-Student Curriculum Development Project}

The current project analyzes blog posts written by senior undergraduate students who participated in a co-op curriculum mapping project. Two third-year students and one fourth-year student from the biochemistry co-op program at the University of Guelph worked full-time to analyze the assessment of learning outcomes in the molecular and cellular biology core courses, a set of eight courses that forms the basis of the biochemistry, molecular biology and genetics, and microbiology programs at the University of Guelph (for a detailed account of the project's technical methodology, please refer to Worthington, Dewancker, LaRush, Lackeyram, \& Dawson, [2017]). The purpose of the project was to examine learning outcome assessment in the core courses. The students applied to and interviewed for these paid contractual positions in partial completion of their co-op degree requirements. The students qualified for these positions because they were biochemistry co-op students who experienced success in the core courses; students were not required to be interested in either curriculum mapping or blogging to qualify. The students' tasks included linking course learning outcomes (CLOs) to assessment questions, categorizing assessment questions according to their Bloom's taxonomy level, and writing an evaluation report to summarize the project's findings.

Collectively, the students' involvement began in January 2015 and ended in August 2015; however, each student worked on the project for a different time period (Figure 1). The students worked in a separate building from their supervising professor, but arranged weekly meetings to discuss the project's next steps. Importantly, students were also encouraged to post on private blogs while they were involved in the project. The students were not required to blog; the students had the option of documenting their work via traditional media such as notebooks. From the faculty member's perspective, the blog was initially used for practical purposes: to track work and communicate with the faculty member without direct meetings. Through the commenting functions, the faculty could provide feedback or direction in a posting, or respond to questions. 


\begin{tabular}{|c|c|c|c|c|c|c|c|}
\hline Jan. & Feb. & Mar. & Apr. & May & Jun. & Jul. & Aug. \\
$\mathbf{2 0 1 5}$ & $\mathbf{2 0 1 5}$ & $\mathbf{2 0 1 5}$ & $\mathbf{2 0 1 5}$ & $\mathbf{2 0 1 5}$ & $\mathbf{2 0 1 5}$ & $\mathbf{2 0 1 5}$ & $\mathbf{2 0 1 5}$ \\
\hline \multicolumn{1}{|c|}{ Student 1's timeline (6 months) } \\
\hline \multicolumn{10}{|c|}{ Student 3's timeline (8 months) } \\
\hline
\end{tabular}

Figure 1. Time spent working on curriculum mapping project, by student.

\section{The Use of Blogging to Guide the Co-op Project}

The students were granted access to Confluence (Version 5.7), a private team collaboration software powered by Atlassian (Atlassian Pty Ltd, 2015) with a blogging function available to users. In addition to keeping private notebooks, the students used the blog as an online platform to voluntarily maintain personal blogs about the project. Aside from being encouraged to provide project updates using Confluence, the students were given the freedom to organize and document their work as they saw fit. They did not receive training on nor were they required to read any guiding documents related to blogging, project management, or self-regulation.

As the students blogged frequently, the students and supervising professor discussed the content of the blogs at weekly meetings. Several weeks into the project, the professor requested that the students use the blogs to record task lists describing their activity for the week, but otherwise allowed the students to use the tool at their discretion. Neither students nor supervisor knew that the blogs would be analyzed retrospectively after the end of the project. At the time of the curriculum mapping project, the sole purpose of the blog was to manage the project.

\section{Method}

\section{Author Roles}

The current study involves active contributions from some of the researchers who participated in the curriculum mapping study. The first author of this paper (PW) was one of the undergraduate co-op students who worked on the curriculum mapping project. The fourth author (JD) was the supervising professor on the curriculum mapping project. The third author (DL) was a consultant on the curriculum mapping project. The second author (JR) was uninvolved with the curriculum mapping project and was brought into the current study after the mapping project was complete.

\section{Data Source}

Data for this study consisted of transcripts from the password-protected blog posts written by the three students involved in the curriculum mapping project (including PW, the first author of this paper). Research Ethics Board approval for secondary use of data was obtained after the completion of the initial curriculum mapping project (REB\#16AUo18) and the three co-op students consented to analysis of their blog posts for the current study. 


\section{Analytical Approach}

To address Research Question 1, we counted the number of blog posts written by each student, and used Microsoft Word's word count feature to determine the length of each post. To analyze how students used the blog, we analyzed the blog posts using inductive content analysis. Content analysis allows researchers to synthesize and make sense of qualitative data by identifying categories or themes in the data (Patton, 2002). The second author (JR) read transcripts of the blog posts closely several times, and made note of potential themes. Next, the first and second authors developed a codebook based on the close reading of the transcripts. The second author then coded all blog posts using NVivo (Version 11; QSR International, 2016), a qualitative analysis software program Our interest was in examining what students wrote about and how students used the blog to address Research Questions 2 and 3. Therefore, we focused the qualitative analyses on two major areas: the content of the blog posts and the functions of the blog posts.

The first-listed author (PW) used her personal experiences and expert knowledge of the curriculum mapping project to validate and help shape the discussion points in this paper. The other two students were not contacted for any additional member checking protocol.

\section{Results}

\section{Frequency of Posting}

On average, each student wrote seven posts per month, and the average blog post was 568 words long (Table 1). The number of posts and words written by each student corresponded to the length of co-op term, with the student with the longest co-op term authoring the most posts.

Table 1. Number of Blog Posts by Student

\begin{tabular}{llll}
\hline Student & Number of blog posts & Total number of words & Blogging period \\
\hline Student 1 & 46 & 22959 & 6 months \\
Student 2 & 29 & 14860 & 4 months \\
Student 3 & 51 & 33726 & 8 months \\
\hline
\end{tabular}

\section{Content of Blog Posts}

The students used the blog to write about curriculum-related issues and for personal reflection.

Curriculum-related blog posts. The blog was used as a place for the students to record their thoughts about the curriculum-assessment alignment project. Just as a blog used to reflect on experiences in a medical school rotation tends to focus on topics related to medicine (e.g., Chretien et al., 2008), the majority of the blog posts related to the curriculum-assessment project focused on pedagogy, including curriculum mapping, constructive alignment, learning outcomes, exam questions, and Bloom's Taxonomy. In the following excerpt, a student describes how she distinguishes between course learning outcomes (CLOs) and concepts: 
I have some opinions on the difference between concepts and CLOs. [Professor] initially wrote his concept list as CLOs, so they follow the CLO form: verb and some sort of scientific context. While we have been discussing the concept assignments, we realized that the specific wording is more important when assigning concepts. This is because in concepts, the larger verbs (ie explain, compare) do not act as an umbrella that encompasses the smaller verbs (ie list, describe). The only "umbrella"-like wording is when the concepts say the student should "describe" something that is "related to" or "involved with" something else. (Student 3)

The blog was designed to act as a record for the curriculum-assessment alignment project. Therefore, students wrote extensively about the pedagogy of curriculum mapping, and recorded team decisions about the mapping process. Consequently, the blog served as a mechanism to guide the mapping work.

Personal reflection. Another use for the blog fell outside of the realm of pedagogy. The students sometimes used the blog to reflect. For example, the blog was used as a space to describe challenges the students faced on the job (e.g., time management, motivation, clear communication with other team members), or to reflect on how knowledge they learned on the project could be applied to the rest of their lives. Two of the students also used the blog to set personal learning goals to work toward over the course of the coop placement. One student wrote a post to describe her goal of developing creative and useful resources:

${ }^{*}$ Goal 3: In this next phase of the project, our job will be to create resources. I want the resources I create to meet our standards, but I also want them to be original. Similar to one of my previous co-op goals, this will require a good balance of conformity and creativity. (Student 3)

In this excerpt, the student uses the blog as a place to formally state a work-related goal and she includes an action plan and measure of success, as is required by the co-op program. The goal is linked to one of the University's Undergraduate Learning Outcomes, demonstrating that the student uses the blog to reflect on what she has learned and apply it to personal goal setting. To promote self-reflection, instructors often encourage students to blog (e.g., Chretien et al., 2008). Without specific direction to do so, the students involved in this project used the blog to share these important resolutions.

\section{Function of the Blog Posts}

The three co-op students who completed the curriculum-assessment alignment project used their blogs in several ways. On an organizational and administrative level, they used the blog to track accomplished and pending tasks. The blog also allowed them to communicate with their faculty supervisor and with one another through internal commenting functions. These uses of the blog helped to organize and guide the mapping project.

Higher-order cognitive functions were demonstrated on the blogs when students used the blog as a place to store notes on relevant pedagogy-related literature, including summaries of conference presentations that they attended, webinars, and scholarly literature. They evaluated and critiqued the literature and applied their learning to the course learning outcomes (CLOs) in the curriculum-assessment alignment project. They 
created records of their original creations on the blog, such as revised CLOs, sample exam questions, and unique processes to guide the curriculum-assessment alignment project. Overall, the students' use of the blog demonstrates that a project blog used during a co-op placement can be a useful tool for organization, communication, application, reflection, and creation. The next section describes the five functions of the blog.

Tracking tasks and hours. One of the students noticed that work was being duplicated and approached the faculty supervisor, who suggested that the blog could be used to track tasks. The students then used the blog to track tasks accomplished both individually and as a team, and also used the blog as a to-do list and to track hours worked. This format emerged as a way for team members to clearly communicate to the faculty supervisor and to one another tasks that had been accomplished and tasks that still needed to be done. This process clarified tasks within the team and helped to mitigate the problem of work being missed or duplicated. The following blog post listing accomplished tasks is typical of this function of the blog:

- Researched online learning and assessment ideas

- Extended search to the key components to creating good questions

- Continuing to write blog highlighting the key ideas that I have uncovered (Student 2)

One student used the blog almost exclusively for administrative task tracking, while the other two students used the blog more extensively. The administrative and organizational function of the blog is the most straightforward use of the blog, but is nevertheless helpful. In contrast to tracking hours and tasks accomplished and pending in a personal lab notebook or calendar, team members shared this information, thus improving their productivity and teamwork.

Enhancing team communication. A blog is a social medium, where authors can address others directly and users are encouraged to comment on one another's work. The students used the blog to communicate directly and indirectly with their faculty supervisor and the other members of their team. This dialogic quality raised the function of the blog above a personal notebook to a powerful communication tool. All three students included notes to one another and their professor throughout their posts, and the majority of posts included at least one comment from another team member. Sometimes the notes involved asking for feedback or clarification on an idea or process. For example, one student directly addresses the faculty advisor to gain clarification on the materials that will be coded for the curriculum-assessment alignment project:

Today I noticed that [course] did not have many assessment materials in the folder on the secure drive. From personal experience with that course, a lot of the assessment was from lab work and group assignments. We could pick apart the lab report data sheets for questions, but that makes me wonder if the other courses have the lab-component, or other CEA questions besides midterms and finals. How extensive is our approach here? I think that learning outcomes analysis should encompass the entire course assessment, not just midterm and final. Some courses only have those CEA's, and others have completely different structures. [Professor] are the questions and assessments that are on the secure server now the only ones that we will get, or are there still more on the way? (Student 1) 
In this post, the author summarizes the problem (i.e., the secure server seems to be missing some course-related assessments) and directly addresses the faculty supervisor for clarification. This question could also be asked in person or via email, but by asking the question on the blog, the student ensures that the information will be communicated with the whole team. She is also able to clarify her thought process behind the question to make sure it is correctly understood. Several such instances of direct questions for the faculty advisor and other team member were posed by blog authors and answered in the blog comments, helping to improve communication between the team members.

Other blog communications involved friendly notes to the faculty member or the other students. The students often used the blog to thank the other members of the team for their help with a difficult task, or took the opportunity to thank the faculty supervisor for the experience. This type of post may have helped strengthen team cohesiveness and promote a sense of connection between the students and the professor.

Summarizing information. Another common function of the blog was as a place to summarize literature on learning outcomes, constructive alignment, and Bloom's Taxonomy. Two of the students who participated in the curriculum-assessment alignment project used the blog extensively to summarize resources on these topics. They wrote notes about conference presentations, webinars, and journal articles. This function of the blog allowed the students to summarize their thoughts on the literature, and also served a knowledge translation function so that the rest of the team could benefit from the blog author's learning. These summaries of resources were typically less formal than an academic literature review, for example, and they often incorporated the student's reflections and evaluations of the content. For example, in the excerpt below, one student summarizes information on learning outcomes from several academic sources:

Speak to the learner - learning outcomes should address what the learner will know or be able to do at the completion of the course

Measurable - learning outcomes must indicate how learning will be assessed

Applicable - learning outcomes should emphasize ways in which the learner is likely to use the knowledge or skills gained (Student 2)

By summarizing this type of information on the blog, as opposed to in personal notes, the student shares the information with the entire team. This function makes the blog a useful reference for the author of the particular post but also for the rest of the team.

The students also used the blog to share links to resources and to upload documents for their own and others' future reference. This use makes the blog a convenient resource hub for students to consult and helps them organize information in an easily accessible place.

Brainstorming ideas for the project. Beyond summarizing literature related to curriculum mapping, the students also used the blog as a place to brainstorm ideas for the curriculum-assessment alignment project. These brainstorming blog posts often took the form of a description of an issue that the student was working on, followed by the student processing the issue. For example, the student might describe a problem or hurdle in the project, and then describe the pros and cons of different plans of action. Sometimes the student would address the faculty member or the other students to get feedback. Often, 
the student concluded the post by offering her suggestion on the best course of action, along with a justification for the plan. This excerpt shows one of the students reflecting on the importance of having students involved in creating learning outcomes (LOs) for a course and brainstorming some methods to involve students in the process:

Another idea which works for smaller classes is to have students take ownership for the outcomes by creating them for themselves!...I wondered if the students have any role currently in developing learning outcomes, besides the evaluation forms (if those are used in LO development). Can the student representatives on the [undergraduate curriculum committee] provide an opportunity for faculty to get that student perspective on LO writing? (Student 1)

In another example of using the blog as a place to brainstorm solutions, a student described the issue of making the method of the curriculum-assessment alignment project "sustainable" and offered a potential solution:

The other thing I want to consider here is sustainability. If we add new questions, how can we link them to similar existing questions? Perhaps the best strategy is to develop a set of similar questions pertaining to specific content and CLOs at a time. (Student 1)

In this third example, one of the students suggests a solution to a problem that the group had been struggling with. The student suggests a way to test whether concepts and CLOs can be assigned together, or whether they must be assigned independently. She writes:

So, here is a small experiment that we can do to figure out which situation we are dealing with. We will attempt to write a question that targets a concept without targeting all of the "aligned" CLOs. If we are able to do this, we have proved that concepts and CLOs must be assigned independently of each other, that they are not as linear as we previously thought. If we are unable to do this we have validated our current belief, that the concept is an absolute indicator of relevant CLOs. Additionally, we should try to write questions that target CLOs without targeting concepts. (Student 3)

This blog post allows the students to reflect upon their colleague's thoughts on a complex issue and a potential mechanism that may help them solve a problem. The blog provided a location for students to think through complex issues in writing. Students engaged in the process of reflection in these brainstorming posts by applying the literature to their current context, evaluating pros and cons, and proposing innovative solutions. The use of a blog to record notes on a project may encourage student learning by providing a space for students to reflect upon the project and the literature.

Evaluating the literature and existing course learning outcomes (CLOs). The blog served as a place for the students to evaluate and critique existing learning outcomes, exam questions, and concepts from the literature. In this context, the blog functioned as a place for students to practice higher-order cognitive skills. Instead of simply stating that a CLO is good or bad, for example, the students gained skills by defending a position and proposing a solution. In the following excerpt, one of the students lists the 
learning outcomes for a course included in the curriculum-assessment alignment project and then critiques the learning outcomes.

Upon initial reading, these CLOs fit great with the course! In fact, they align chronologically with the lectures, so anyone who has taken the course should have some sort of an idea of which topics are targeted by each CLO. I think this is a great idea, it is very user-friendly. There are a couple concerns though and I think that there are two types: 1 . The CLOs do not align well with some questions and 2 . There is a lot of overlap between some CLOs, making it hard to distinguish them. Below, I will expand on these ideas. (Student 3)

In this blog post, the student provides an overall assessment of the CLOs and provides evidence to support her position (e.g., the outcomes are presented in the same order as the course material). She also describes the problems with the learning outcomes. Following this excerpt, the student includes examples of specific questions that do not align with the CLOs. She describes what aspect of the question or learning outcome is misaligned, and offers solutions to improve the alignment. The student also critiques specific aspects of learning outcomes, for example, by pointing out when a learning outcome covers too much. Again, the student offers a solution to the problem, in this case by re-writing the learning outcome. This type of blog post required the student to apply her knowledge of CLOs and Bloom's Taxonomy to her knowledge of the course content (in this case, biochemistry). The blog allowed the students to disseminate this type of detailed analysis, which may be difficult to do elsewhere. For example, this type of analysis may not be appropriate to share over email (where conventions may have prevented this type of detailed communication) or in a meeting (e.g., where time constraints may not allow the analysis).

Documenting team creations. Another important use for the blog was as a place for the students to document processes, solutions, and resources that they created individually and as a team. These types of blog posts included summaries of the workshops and presentations that the group presented at conferences and descriptions of rules or processes that the team created for the curriculum-assessment alignment project. Here, one student describes an observation that the team devised about broad or overarching CLOs:

It is difficult, but still possible, to make overarching CLOs. They should focus on connecting different units of study together. Beware: this type of CLO might translate into "understand everything", which is not what we are aiming for!! (Student 3)

Students also recorded revised learning outcomes, and created questions that targeted specific Bloom's Taxonomy levels. Therefore, the blog served as a place to record examples, rules, and processes established for the project. By posting these creations on a blog, they were visible to all members of the team, which may have helped the students collaborate effectively.

\section{Discussion}

Co-op work terms require that students engage in meaningful work and learn and reflect upon that work. Blogging may be a useful tool for students to fulfill both of these tasks. Over the course of the co-op work term described in this paper, three students used 
a private blog to communicate with one another, track tasks, brainstorm, and reflect. Despite no explicit requirement regarding how often to post, nor grades associated with posting, students used the blog extensively and in varied ways. This finding expands the literature on student engagement with blogging by suggesting that it is not always necessary to provide grades for blog posts (e.g., Chu et al., 2012). The use of the blog helped to organize the team members, who were separated by location and time of work. The blog streamlined communication between team members, encouraged collaboration, and gave students a place to engage in reflection. These uses suggest that the blog played an important role in guiding the mapping project and may have promoted student learning.

In this qualitative study, we focused on how the three students used the project-related blog. Because of the nature of the project, we cannot offer causal explanations for why the blog was used so extensively. However, we believe that certain characteristics of the blog, the students, and the project may have contributed to the successful use of the blog as a tool to manage a collaborative project and to support student learning and reflection. Below, we offer explanations for three major observations: the diverse functions of the blog, the frequent postings, and the deeply written posts.

\section{Frequent Postings}

During the co-op work term, students structured their blog posts autonomously, posted as often as they wanted, and did not receive grades for posting. In contrast to literature that suggests that students engage more often with blogging when they receive a grade for posting (e.g., Chu et al., 2012) students posted frequently throughout the project, each publishing an average of seven posts per month. The blog's usefulness may have inspired this consistent and frequent activity. The blog was used to communicate information amongst the team members, which helped to ensure that the project ran smoothly despite differing student schedules and locations on campus. The faculty supervisor (JD) reported that although the blog was initially intended for the practical purpose of guiding the project, as the project progressed the blog became a way for the students to evolve the project beyond its initial goals into a richer undertaking through posting new ideas and collaborative discussions with the faculty member.

Theories concerning intrinsic motivation suggest that the students may have used the blogs so extensively because they were not rewarded with grades for doing so. Research on intrinsic motivation and grading shows that students' feelings of autonomy, and not grades, predict their continued motivation for a task (Pulfrey, Darnon, \& Butera, 2013). Granted, as the students authored meaningful blog posts that were valued by the faculty supervisor and team members, the students may have become more extrinsically motivated to continue blogging. Our results suggest that as long as a blog is useful for students, they may engage with it, even without explicit grades associated with posting.

\section{Diverse Functions of the Blog}

Our content analysis revealed that the students wrote blogs with many different purposes (task lists, summaries, brainstorming, contributions to the wider scholarship of teaching and learning community). This dynamic usage was facilitated by the blog's 
amorphous nature and may not have been possible with a more rigid framework. The students may have been inspired to embrace the blog's versatility because they were not told what the posts should look like. The freedom given to the students allowed them to use the blog in ways they thought would be useful. As a result, the blogs were used creatively to contribute to the team's accomplishments.

\section{Deeply Written Posts}

Many posts were written thoughtfully and with elements of high-order cognitive skills. These types of posts were frequently authored by Student 1 and Student 3, who were hired at the beginning of the project and helped design the project's protocols. They used the blogs to brainstorm, discuss, and reflect on ideas and potential solutions to the project's initial challenges. Student 2 was hired after most of the obstacles had already been resolved, and so did not have the same opportunity to participate in method development and organization. All three students were highly motivated individuals who competed for their paid positions, and were selected by the faculty supervisor to work on this project. Because the students were hired for the project full-time, they were able to fully invest their thinking into their work, generating insightful material to blog about.

\section{Limitations}

Our analysis of the use of a blog to guide a large-scale pedagogical project suggests that the blog was crucial to the project's success, and provided students with an outlet to practice reflection. However, the analysis is limited to a case study of a single project involving three highly motivated students. Therefore, our results may not be generalizable to larger projects or projects involving a different population of bloggers. Despite the small number of student bloggers, we argue that the extensive use of the blog and the resulting large dataset consisting of over 100 blog posts yields a substantial enough dataset to conduct qualitative analyses with rich rigor (Tracy, 2010). In addition, our analyses cannot directly assess whether the use of the blog promoted learning. However, the nature of the blog posts involving collaboration, communication, and reflection, strongly suggest that the use of the blog set the stage for informal learning to occur through discussion and introspection (e.g., sharing perspectives and suggestions through the commenting function and mentally processing challenging situations). Future research examining the use of a blog to guide a project and promote learning could include interviews or surveys with blog authors to more directly assess the effect of the blog on the users.

\section{Conclusion}

In this study, we examined students' use of a project-related blog on a curriculum project. We found that students used the blog extensively, to communicate with their faculty supervisor and with one another, to brainstorm solutions to problems, to record notes, and to critique existing learning outcomes and the literature. Arguably, the blog helped the students achieve two co-op requirements, accomplishing work and learning and reflecting on the work, by facilitating communication, enhancing organization, and providing a space to reflect and learn. 
The students' deep engagement with the blog may stem from characteristics of themselves, the blog, or the project itself. Instructors who hope to achieve similar levels of student engagement with a course blog could consider using a blog under similar circumstances. For example, senior undergraduate or graduate students working collaboratively on a large project can be given the freedom to utilize a blog to record and reflect on their progress over the course of the project. Future research could examine whether students demonstrate high levels of engagement with course- or project-related blogs under different circumstances, such as in larger classes or using more explicit requirements regarding when to blog.

\section{Acknowledgement}

This research was supported in part by a Learning Enhancement Fund grant from the University of Guelph and support from Open Learning and Educational Support at the University of Guelph.

\section{References}

Chretien, K., Goldman, E., \& Faselis, C. (2008). The reflective writing class blog: Using technology to promote reflection and professional development. Journal of General Internal Medicine, 23(12), 2066-2070. http://doi.org/10.1007/s11606-008-0796-5

Chu, S. K. W., Chan, C. K. K., \& Tiwari, A. F. Y. (2012). Using blogs to support learning during internship. Computers and Education, 58(3), 989-1000. http://doi.org/10.1016/j. compedu.2011.08.027

Churchill, D. (2009). Educational applications of Web 2.0: Using blogs to support teaching and learning. British Journal of Educational Technology, 4O(1), 179-183. http://doi.org/10.1111/j.1467-8535.2008.00865.x

Confluence (Version 5.7) [Team collaboration software]. (2015). Sydney, Australia: Atlassian Pty Ltd.

Co-operative Education and Work-Integrated Learning Canada (CEWIL). (n.d.). Co-operative Education Definition. Retrieved from http://www.cewilcanada.ca/coopdefined.html

de Andrés Martínez, C. (2012). Developing metacognition at a distance: Sharing students' learning strategies on a reflective blog. Computer Assisted Language Learning, 25(2), 199-212. http://doi.org/10.1080/09588221.2011.636056

Divitini, M., Haugaløkken, O., \& Morken, E. M. (2005). Blog to support learning in the field: lessons learned from a fiasco. Proceedings of the 5 th IEEE International Conference on Advanced Learning Technologies (ICALT 2005), 219-221. http://doi.org/10.1109/ ICALT.2005.74

Edgar, S., Francis-Coad, J., \& Connaughton, J. (2013). Undergraduate reflective journaling in work integrated learning: Is it relevant to professional practice? Asia-Pacific Journal of Cooperative Education, 14(3), 147-156.

Halic, O., Lee, D., Paulus, T., \& Spence, M. (2010). To blog or not to blog: Student perceptions of blog effectiveness for learning in a college-level course. Internet and Higher Education, 13, 206-213. http://doi.org/10.1016/j.iheduc.2010.04.001 
Makri, K., \& Kynigos, C. (2007). The role of blogs in studying the discourse and social practices of mathematics teachers. Educational Technology and Society, 1O(1), 73-84.

Miceli, T., Murray, S. V., \& Kennedy, C. (2010). Using an L2 blog to enhance learners' participation and sense of community. Computer Assisted Language Learning, 23(4), 321-341. http://doi.org/10.1080/09588221.2010.495321

Mortensen, T. and Walker, J. (2002). Blogging thoughts: personal publication as an online research tool. Morrison, A. (Ed.). Researching ICTs in context (Research report 3/2002). Retrieved from http://citeseerx.ist.psu.edu/viewdoc/download?doi=10.1.1.156 $.7392 \&$ rep $=$ rep1\&type $=$ pdf $\#$ page $=257$

NVivo (Version 11) [Qualitative analysis software]. (2016). Melbourne, Australia: QSR International.

Patton, M. Q. (2002). Qualitative research and evaluation methods (3rd ed.). Thousand Oaks, CA: SAGE Publications, Inc.

Pulfrey, C., Darnon, C., \&Butera, F. (2013). Autonomy and task performance: Explaining the impact of grades on intrinsic motivation. Journal of Educational Psychology, 105(1), 39-57.http://doi.org/10.1037/a0029376Sawmiller, A. (2010). Classroom blogging: What is the role in science learning? The Clearing House: A Journal of Educational Strategies, Issues and Ideas, 83(2), 44-48. http://doi.org/10.1080/o0098650903505456

Strampel, K., \& Oliver, R. (2008). We've thrown away the pens, but are they learning? Using blogs in higher education. In Hello! Where are you in the landscape of educational technology? Proceedings ascilite Melbourne 2008, Retrieved from http://ro.ecu.edu.au/ ecuworks/933

Tracy, S. J. (2010). Qualitative quality: Eight "big-tent" criteria for excellent qualitative research.QualitativeInquiry,16(10),837-851.http://doi.org/10.1177/1077800410383121

Worthington, P., Dewancker, A., LaRush, N., Lackeyram, D., \& Dawson, J. F. (2017). Engaging student stakeholders in developing a learning outcomes assessment framework. In Discussions on University Science Teaching: Proceedings of the 2015 Western Conference on Science Education, 1(1), 8. Retrieved from https://ir.lib.uwo.ca/ cgi/viewcontent.cgi?article $=1000 \&$ context $=$ wcsedust

Xie, Y., Ke, F., \& Sharma, P. (2008). The effect of peer feedback for blogging on college students' reflective learning processes. Internet and Higher Education, 11, 18-25. http:// doi.org/10.1016/j.iheduc.2007.11.001

Yang, S. H. (2009). Using blogs to enhance critical reflection and community of practice. Educational Technology \& Society, 12(2), 11-21. http://doi.org/10.2307/ jeductechsoci.12.2.11

\section{Contact Information}

Paisley Worthington

Department of Molecular and Cellular Biology

University of Guelph.

pworthin@uoguelph.ca 
Paisley Worthington is a master's student in the Department of Molecular and Cellular Biology. Her research is focused on developing a method to understand and visualize how students are able to advance their problem-solving skills over the course of an undergraduate degree. She has presented to numerous audiences throughout Ontario on various topics, including critical thinking, learning outcomes, and curriculum mapping.

Jennifer Reniers is an Educational Analyst working in the Department of Open Learning and Educational Support at the University of Guelph. Jennifer's role involves collaborating with faculty and staff across the university to assess the achievement of learning outcomes. Jennifer's work involves conducting surveys, interviews, and focus groups with students and other stakeholders, leading curriculum mapping projects, and consulting on faculty projects concerned with the scholarship of teaching and learning. Jennifer holds a $\mathrm{PhD}$ in Applied Social Psychology from the University of Guelph.

Dale Lackeyram is the Associate Director, Educational Development in the Department of Open Learning and Educational Support at the University of Guelph. Dale and his team lead efforts to improve student learning by supporting the teaching, learning, and assessment effort at the university. Dale is also involved in and leads many projects related to assessing student learning outcomes at the program level and collaborates with institutions, faculty, and staff across the university sector. He has contributed to numerous provincial reports and publications on student learning and learning outcomes assessment. Dale holds a PhD in Physiology, and has worked in curriculum for 17 years at the University of Guelph.

John Dawson is a full professor in the Department of Molecular and Cellular Biology and founding Director of the College of Biological Science Office of Educational Scholarship and Practice (COESP) at the University of Guelph. His education research is focused on applying learning outcomes to curricula and student learning. He led the first curriculum mapping in his department using learning outcomes he developed for their majors. He is currently involved in bringing local education researchers together to form the BioEd Research Hub at Guelph. Their first study investigates the ways faculty use student evaluations of teaching to inform teaching practice. 